\title{
Roof Fracture Characteristics and Strata Behavior Law of Super Large Mining Working Faces
}

\author{
Guozhen Zhao $\mathbb{D}^{1,2}$ Baisheng Zhang $\mathbb{D}^{1,}{ }^{1}$ Lihong Zhang, ${ }^{3}$ Chao Liu, ${ }^{1}$ and Shuai Wang ${ }^{1}$ \\ ${ }^{1}$ College of Mining Engineering, Taiyuan University of Technology, Taiyuan, Shanxi, China \\ ${ }^{2}$ Key Laboratory of In-situ Property-Improving Mining of Ministry of Education, Taiyuan University of Technology, Taiyuan, \\ Shanxi, China \\ ${ }^{3}$ State Environmental Protection Key Laboratory of Efficient Utilization Technology of Coal Waste Resources, Institute of Resources \\ and Environmental Engineering, Shanxi University, Taiyuan, Shanxi, China
}

Correspondence should be addressed to Guozhen Zhao; zgzcumts@163.com

Received 17 July 2021; Accepted 11 August 2021; Published 3 September 2021

Academic Editor: Zhijie Wen

Copyright (C) 2021 Guozhen Zhao et al. This is an open access article distributed under the Creative Commons Attribution License, which permits unrestricted use, distribution, and reproduction in any medium, provided the original work is properly cited.

\begin{abstract}
Exploiting the working face in coal mines using a super long mining length and large mining height has become important for intensive production with high yield and high efficiency. The paper develops a roof structure model to analyze the influence of $195 \mathrm{~m}, 242.4 \mathrm{~m}$, and $376 \mathrm{~m}$ working face lengths at large mining height in Wangzhuang Coal Mine in China as the case study. The roof fracture characteristics, migration law, and strata behavior law under different working face lengths are compared and studied by numerical simulation, and the reliability of support selection in the working face at large mining height is analyzed by field measurement statistics. The results show that the roof fracture mode of a super large working face is a successive layered fracture. The length of the working face has little effect on the roof fracture step length, and the fracture step length is positively correlated with the thickness of the rock stratum. The roof subsidence law for a super large working face is different from the intermittent subsidence of the unimodal Gaussian distribution curve of ordinary working faces, which shows the intermittent subsidence of multiple ordinary working faces. The roof periodic weighting of a super large working face, which fluctuates violently within $100 \mathrm{~m}$ at both ends, is more drastic than that of an ordinary working face as a whole. Field statistical analysis shows it is more appropriate to choose high-strength support for a super large working face.
\end{abstract}

\section{Introduction}

With the rapid growth of the world economy, the market demand for coal continues to increase year by year, and highyield and highefficiency coal mines are increasingly common [1-5]. After years of development, full-height fully mechanized mining at one time has become an important technology for highyield and highefficiency mining in thick coal seams [6]. In addition to increasing the mining height, increasing the length of the working face has become a new direction for high yield and high efficiency working face mining [7]. It is generally considered that a working face with a length of more than $250 \mathrm{~m}$ is a super large face [8]. Lengthening the working face can improve the per unit yield of the working face and simplify the production system and reduce coal loss, which all enhance mine productivity. Super large working face production technology has become a crucial development direction for intensive coal mine production technology [9].

In recent years, research on super large working faces has mainly focused on medium-thick coal seams. In 2002, the average length of longwall working faces in Australia was $227 \mathrm{~m}$, the average annual distance was $2,160 \mathrm{~m}$, and the average yield of working faces was 2.82 million tons [10]. In 2004, the length of some fully mechanized coal mining faces in the United States was close to $300 \mathrm{~m}$, the maximum advancing length was $4,580 \mathrm{~m}$, and the average yield of working faces increased from 1.52 million tons to 3.26 million tons [10]. According to incomplete statistics, there are 11 working faces over $300 \mathrm{~m}$ long in the United States and 18 in Germany, with the longest working face of $506 \mathrm{~m}$ (coal seam thickness of $1.9 \sim 2.3 \mathrm{~m}$ ) [11]. Russia, 
Poland, and other major coal producing countries are also developing super large working faces. In 2007, the first super large working face of $400 \mathrm{~m}$ (with an average thickness of $1.7 \mathrm{~m}$ ) was put into production in China at the Yujialiang Coal Mine in Shendong Mining District of the Shenhua Group [12]. In 2012, the longest face was the $450 \mathrm{~m}$ fully mechanized working face (with an average thickness of $2.11 \mathrm{~m}$ ) at the Halagou Coal Mine in Shendong Mining District $[13,14]$.

While lengthening working faces, China is also researching very high working faces for thick coal seams. In 2005, Shangwan Coal Mine in Shendong Mining District built the world's first fully mechanized coal mining face a lengthened working face with a large mining height of $300 \mathrm{~m}$ and average coal seam thickness of $5.5 \mathrm{~m}$ [15]. In 2008, Shangwan Coal Mine completed the design of a lengthened thick working face with a large mining height of $300 \mathrm{~m}$ and average coal seam thickness of $5.5 \mathrm{~m}$, which is the world's first fully mechanized mining working face with yield of over 10 million tons [15]. In July 2010, in high gas conditions, the fully mechanized mining technology for large mining height was applied in the Dongsi Panel of the Sihe Coal Mine of the Jincheng Anthracite Coal Mining Group, and a $300 \mathrm{~m}$ super large working face was successfully mined with an average thickness of $6.2 \mathrm{~m}$ [16].

To sum up, working faces of $300 \mathrm{~m}$ length are mainly concentrated in medium-thick coal seams [17], and the thick coal seam mining is difficult; so, the application is relatively less. The increase of face length and mining height will form a larger roof structure, which will exert more load on face supports. Thus, when the length of the working face increases, the roof will present new deformation and loading characteristics, which is a very important and meaningful topic.

This paper systematically compares and studies the roof fracture characteristics and strata behavior of long working faces using field investigation, theoretical analysis, and numerical simulation $[18,19]$. The study uses the coal seam occurrence status and mining characteristics of the 3500 Working Face, which has large mining height, in the Wangzhuang Coal Mine in China. The 3500 Working Face is a typical working face with variable sizes. The working face length has experienced three stages: $242.4 \mathrm{~m}, 195 \mathrm{~m}$, and $376 \mathrm{~m}$, and the average thickness of coal seams is $5.02 \mathrm{~m}$. It is a fully mechanized full-seam large coal mining working face. This working face provides a practical basis for the comparative analysis of the mine pressure behavior law of working faces with different lengths, and therefore, it has vital theoretical and practical value.

\section{Case Study Overview}

The 3500 Working Face of the Wangzhuang Coal Mine is located in the south of Dongzhang Village in Changzhi, Shanxi Province, China. The mined coal seam is the No. 3 coal seam, in the No. 35 mining area. The average burial depth of the 3500 Working Face is $200 \mathrm{~m}$, and the strike length is $1,066.4 \mathrm{~m}$. The 3500 Working Face is located in the north of the No. 35 mining area, $50 \mathrm{~m}$ away from the
3403 Working Face in the east (mined in 2011), three main roadways of Nanyi in the west, the 3401 Working Face and 3402 Working Face and villages in the north, and the 3501 Working Face in the south (mined from 2013 to 2014). It is shown in Figure 1. The length of the working face at the section of $231 \mathrm{~m}$ away from the cut of the 3500 Working Face in the original design is $242.4 \mathrm{~m}$, and that at the remaining sections is $195 \mathrm{~m}$. In the north of the original 3500 Working Face, another working face ( $149.5 \mathrm{~m}$ in length and delineated by the prospect entry in the No. 35 Mining Area North) exists, and the net coal pillar size between the working faces is $20 \mathrm{~m}$. To improve the recovery rate of coal resources, the No. 35 Mining Area in the north of the original 3500 Working Face and the original 3500 Working Face has been integrated into one working face for mining. After reintegration, the 3500 Working Face has the shape of a "knife handle," and it is divided into three parts: length of $242.4 \mathrm{~m}$ in the first part of the working face in the $231 \mathrm{~m} \mathrm{sec}$ tion, length of $195 \mathrm{~m}$ in the middle part in the $320 \mathrm{~m}$ section, and length of $376 \mathrm{~m}$ in the remaining part.

The 3500 Working Face uses a comprehensive retreating mechanized coal mining method of longwall full-seam spontaneous caving mining. The No. 3 coal seam mined through the 3500 Working Face has a thickness of 4.20 to $5.50 \mathrm{~m}$ (average length of $5.02 \mathrm{~m}$ ) and a dip angle of $2^{\circ}-4^{\circ}$. The coal seam roof is mainly composed of carbonaceous mudstone, mudstone, and fine sandstone. The floor is mainly composed of mudstone and fine sandstone. Table 1 summarizes the distribution and the physical and mechanical characteristics of the coal seam and roof strata of the 3500 Working Face.

\section{Analyses of Roof Fracture Characteristics of Super Large Working Faces}

With the advance from open-off cuts of the working face, the suspended roof length of the goaf continues to increase. Due to the action of mine pressure, every rock stratum on the roof will bend, subside, and become distorted, and when the rock stratum reaches its ultimate strength, it will fracture and cave in [20-24]. Based on the level, thickness, strength, and load of rock strata, the influence of different working face lengths on the roof caving step length is compared and analyzed.

3.1. Calculation of Roof Strata Load. The initial caving step length is the main sign to measure the stability of strata behaviors of the working face. Before calculating the caving step length, it is necessary to calculate the load of each rock stratum. Due to the different thickness and lithology of each stratum, the load on the $i$ stratum is calculated according to the following formula:

$$
\left(q_{n}\right)_{i}=\frac{E_{i} h_{i}^{3}\left(\gamma_{i} h_{i}+\gamma_{i+1} h_{i+1}+\cdots+\gamma_{i+n} h_{i+n}\right)}{E_{i} h_{i}^{3}+E_{i} h_{i}^{3}+\cdots+E_{i+n} h_{i+n}^{3}},
$$

where $\left(q_{n}\right)_{i}$ is the load on the $i$ stratum when the $n$ stratum above the $i$ stratum is considered:

$E_{i} \cdots E_{i+n}$ is the elastic modulus of each stratum. 


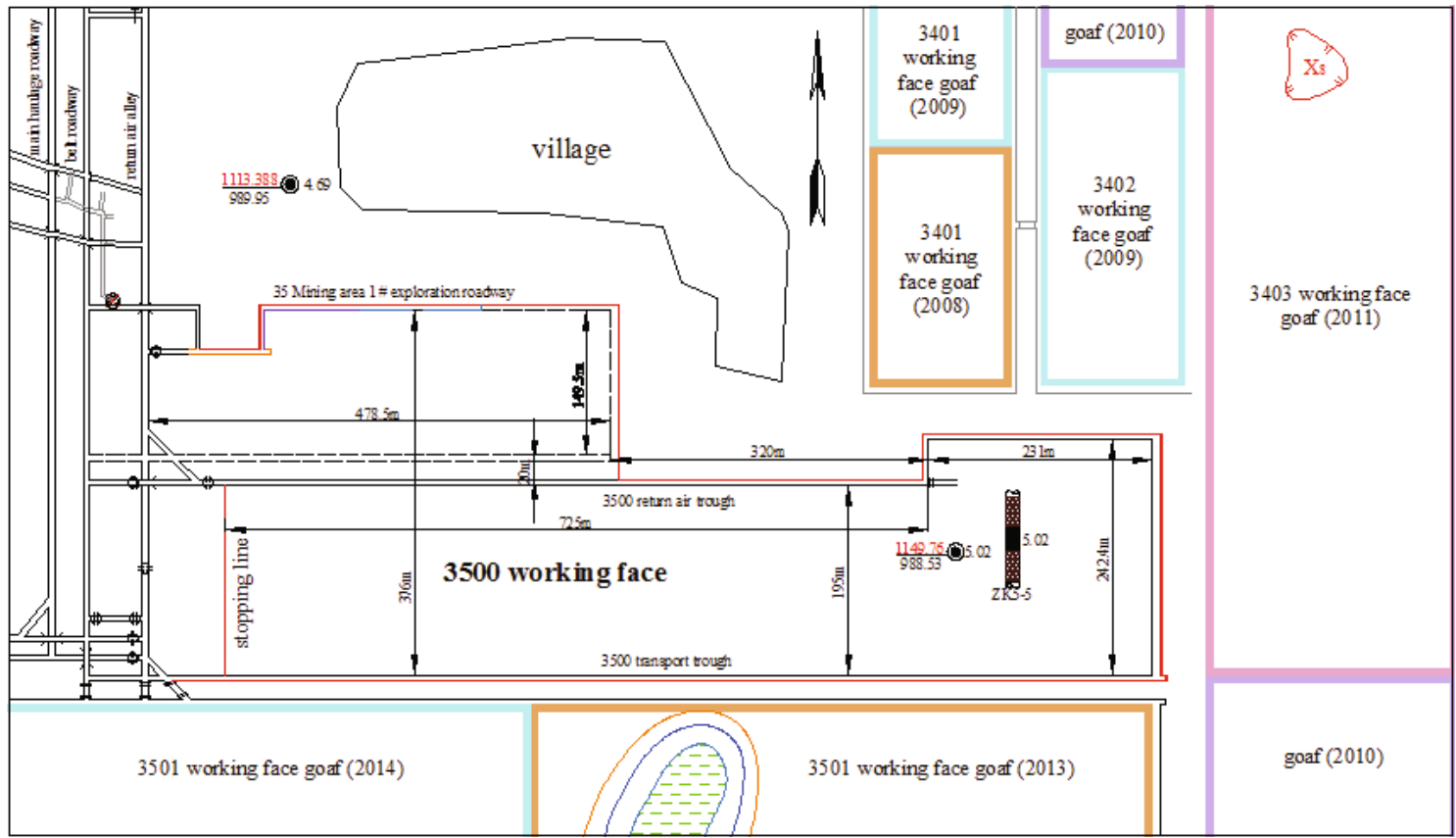

FIGURE 1: Layout of 3500 Working Face and mining dates of goafs.

TABle 1: Distribution and physical and mechanical characteristics of the coal seam and roof strata of 3500 Working Face.

\begin{tabular}{|c|c|c|c|c|c|c|c|}
\hline $\begin{array}{l}\text { Stratification } \\
\text { No. }\end{array}$ & Roof strata & $\begin{array}{l}\text { Thickness } \\
(\mathrm{m})\end{array}$ & $\begin{array}{l}\text { Influence coefficient } \\
\text { of stratification and } \\
\text { joint fracture }\end{array}$ & $\begin{array}{l}\text { Poisson's } \\
\text { ratio }\end{array}$ & $\begin{array}{l}\text { Tensile strength } \\
(\mathrm{MPa})\end{array}$ & $\begin{array}{l}\text { Modulus of } \\
\text { elasticity }(\mathrm{GPa})\end{array}$ & $\begin{array}{l}\text { Apparent density } \\
\left(\mathrm{kg} / \mathrm{m}^{3}\right)\end{array}$ \\
\hline 15 & Fine sandstone & 1.18 & 0.5 & 0.20 & 11.64 & 32.5 & 2673 \\
\hline 14 & Mudstone & 6.0 & 0.35 & 0.22 & 4.21 & 14.3 & 2573 \\
\hline 13 & Fine sandstone & 0.7 & 0.5 & 0.20 & 11.64 & 32.5 & 2673 \\
\hline 12 & $\begin{array}{l}\text { Argillaceous } \\
\text { sandstone }\end{array}$ & 3.0 & 0.45 & 0.24 & 9.76 & 19.7 & 2640 \\
\hline 11 & Mudstone & 8.84 & 0.35 & 0.22 & 4.21 & 14.3 & 2573 \\
\hline 10 & $\begin{array}{l}\text { Argillaceous } \\
\text { sandstone }\end{array}$ & 0.6 & 0.45 & 0.24 & 9.76 & 19.7 & 2640 \\
\hline 9 & Mudstone & 5.22 & 0.35 & 0.22 & 4.21 & 14.3 & 2573 \\
\hline 8 & $\begin{array}{l}\text { Argillaceous } \\
\text { sandstone }\end{array}$ & 1.5 & 0.45 & 0.24 & 9.76 & 19.7 & 2640 \\
\hline 7 & Fine sandstone & 3.7 & 0.5 & 0.20 & 11.64 & 32.5 & 2673 \\
\hline 6 & Mudstone & 0.6 & 0.3 & 0.24 & 4.59 & 14.8 & 2527 \\
\hline 5 & Fine sandstone & 3.7 & 0.5 & 0.20 & 11.64 & 32.5 & 2673 \\
\hline 4 & Mudstone & 1.0 & 0.35 & 0.22 & 4.21 & 14.3 & 2573 \\
\hline 3 & Fine sandstone & 4.6 & 0.5 & 0.20 & 11.64 & 32.5 & 2673 \\
\hline 2 & Mudstone & 1.4 & 0.35 & 0.22 & 4.21 & 14.3 & 2573 \\
\hline 1 & Carbon mudstone & 0.3 & 0.25 & 0.24 & 4.59 & 14.8 & 2527 \\
\hline 0 & No. 3 coal seam & 5.02 & l & 0.33 & 2.33 & 6.3 & 1430 \\
\hline
\end{tabular}

$h_{i} \cdots h_{i+n}$ is the thickness of each stratum.

$\gamma_{i} \cdots \gamma_{i+n}$ is the density of each stratum; $i=1,2,3 \cdots$

When $\left(q_{i+n+1}\right)_{i}<\left(q_{i+n}\right)_{i}$, that is, $\left(q_{i+n}\right)_{i}$ as the load applied to the $i$ stratum, the result of equation (1) is used as the load on the $i$ stratum to calculate its caving step length.
The data in Table 1 is put into equation (1), and the load on each stratum is calculated. The calculation results are shown in Table 2.

3.2. Calculation of Caving Step Length of Each Roof Stratum. For super large working face mining, it is difficult to fully 
TABLE 2: Load, initial caving step length, and periodic caving step length of roof of No. 3 coal seam.

\begin{tabular}{|c|c|c|c|c|c|c|c|c|c|}
\hline \multirow[t]{2}{*}{ Stratification No. } & \multirow[t]{2}{*}{ Roof strata } & \multirow[t]{2}{*}{ Thickness (m) } & \multirow[t]{2}{*}{ Rock stratum load $\mathrm{kN}$} & \multicolumn{3}{|c|}{$\begin{array}{c}\text { Initial caving step length } \\
\text { (m) of each rock stratum } \\
\text { with different working } \\
\text { face lengths }\end{array}$} & \multicolumn{3}{|c|}{$\begin{array}{l}\text { Periodic caving step } \\
\text { length }(\mathrm{m}) \text { of each rock } \\
\text { stratum with different } \\
\text { working face lengths }\end{array}$} \\
\hline & & & & $195 \mathrm{~m}$ & $242.4 \mathrm{~m}$ & $376 \mathrm{~m}$ & $195 \mathrm{~m}$ & $242.4 \mathrm{~m}$ & $376 \mathrm{~m}$ \\
\hline 11 & Mudstone & 8.84 & $>372.4$ & 36.088 & 36.070 & 36.068 & 14.730 & 14.722 & 14.722 \\
\hline 10 & Argillaceous sandstone & 0.6 & 15.48 & 18.460 & 18.460 & 18.460 & 7.535 & 7.535 & 7.535 \\
\hline 9 & Mudstone & 5.22 & 149.8 & 33.594 & 33.582 & 33.580 & 13.712 & 13.707 & 13.706 \\
\hline 8 & Argillaceous sandstone & 1.5 & 39.6 & 28.861 & 28.855 & 28.854 & 11.780 & 11.778 & 11.777 \\
\hline 7 & Fine sandstone & 3.7 & 133.12 & 41.6588 & 41.623 & 41.619 & 17.004 & 16.989 & 16.987 \\
\hline 6 & Mudstone & 0.6 & 15.2 & 12.775 & 12.775 & 12.775 & 5.214 & 5.214 & 5.214 \\
\hline 5 & Fine sandstone & 3.7 & 113.8 & 45.074 & 45.020 & 45.014 & 18.397 & 18.376 & 18.373 \\
\hline 4 & Mudstone & 1.0 & 25.7 & 15.531 & 15.531 & 15.531 & 6.339 & 6.339 & 6.339 \\
\hline 3 & Fine sandstone & 4.6 & 203.3 & 41.911 & 41.874 & 41.869 & 17.106 & 17.091 & 17.090 \\
\hline 2 & Mudstone & 1.4 & 36.0 & 18.372 & 18.371 & 18.371 & 7.499 & 7.498 & 7.498 \\
\hline 1 & Carbon mudstone & 0.3 & 7.58 & 9.045 & 9.0454 & 9.0454 & 3.692 & 3.692 & 3.692 \\
\hline
\end{tabular}

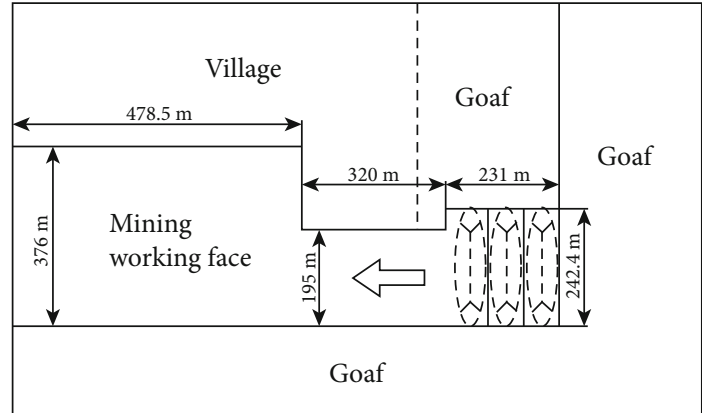

FIgURE 2: Structure model of 3500 Working Face.

define the problem by solving a single plane problem. Therefore, the roof of the coal seam is regarded as a plate structure, and the initial caving step length and the periodic caving step length of each roof stratum are calculated according to plate theories [25], as shown in Figure 2.

The maximum tensile stress intensity theory is used as the fracture criterion of slope roof fracture:

$$
\sigma_{1}=\sigma_{b}
$$

where $\sigma_{1}$ is the maximum tensile stress in the roof, $\mathrm{MPa} ; \sigma_{b}$ is the tensile strength of roof strata, MPa.

The maximum tensile stress of the roof $\sigma_{1}$ is calculated by the following formula:

$$
\sigma_{1}=\frac{M_{\max } y_{\max }}{I}
$$

where $M_{\max }$ is the maximum bending moment acting on the roof strata, MPa.m; $I$ is the area moment of inertia of roof strata, if the section thickness is $h, I=h^{3} / 12$, the unit is 1 ; then,

$$
M=\frac{\sigma_{1} h^{2}}{6} .
$$

Let $l_{m}=h /\left(1-\mu^{2}\right) \cdot \sqrt{2 \sigma_{b} / q}$, where $q$ is the uniform load of the roof, $\mathrm{MPa} ; \mu$ is Poisson's ratio of the rock stratum.

For the island mining face of the three-sided goaf, if the cut length is $242.4 \mathrm{~m}$, all three sides of the mining face are goafs. According to the theoretical analysis of the plate, the initial caving step length is

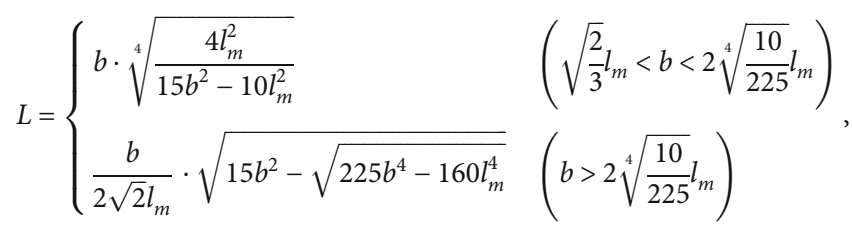

where $b$ is the length of the working face, $m$.

For the working face with two adjacent sides mined out and two adjacent sides fixed, if the cut length is $195 \mathrm{~m}$ and $376 \mathrm{~m}$, the two adjacent sides of the mining working face are goafs, and the others are unexploited solid coal. According to the theoretical analysis of the plate, the initial caving step length is

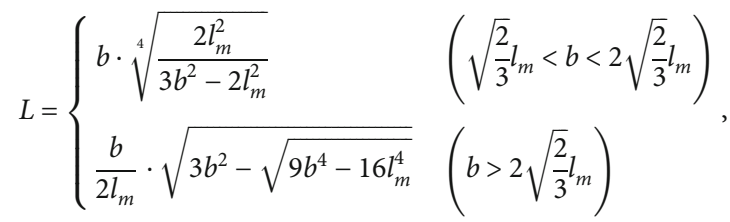

where $b$ is the length of the working face, $m$.

When the working face length of the No. 3 coal seam is $242.4 \mathrm{~m}$, equation (5) is introduced; when the length of No. 3 


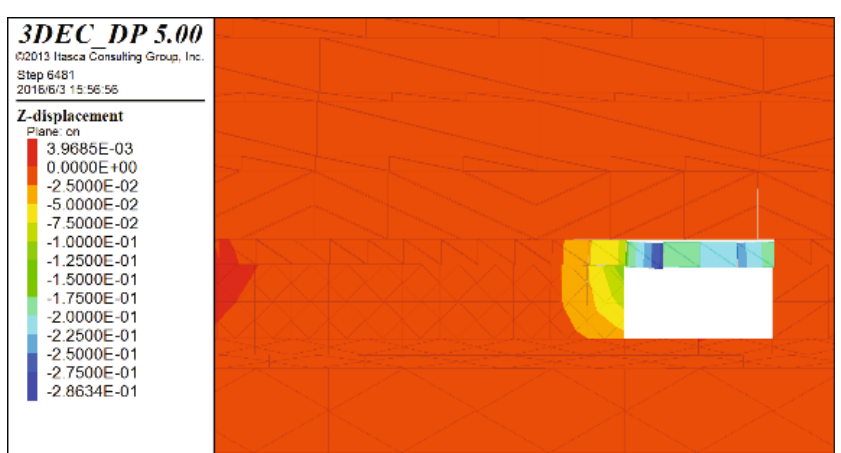

(a)

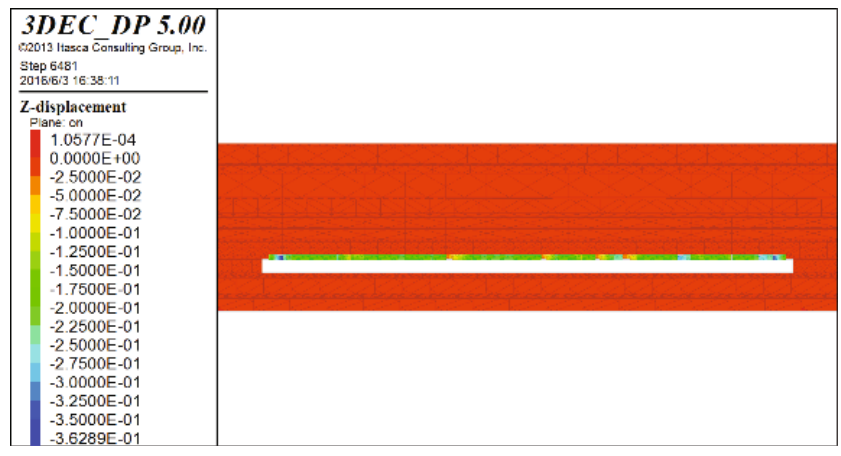

(c)

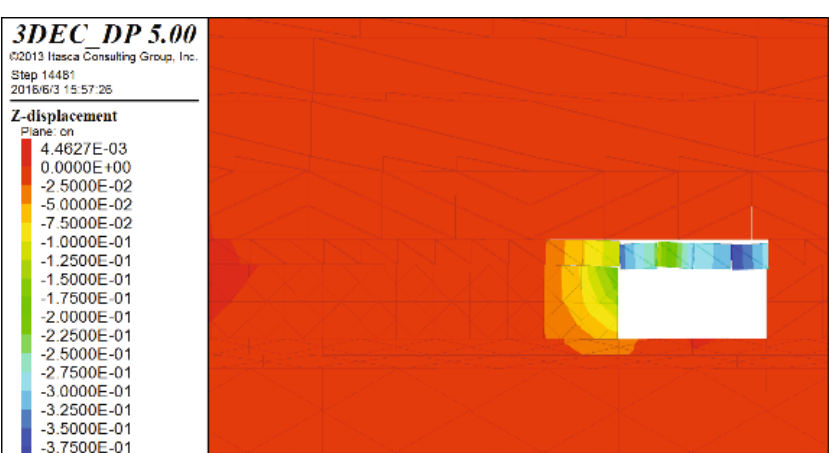

(b)

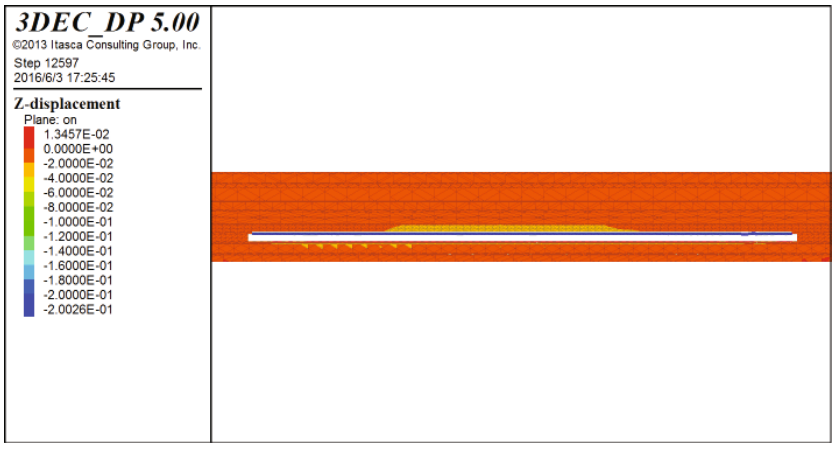

(d)

FIGURE 3: Nephogram of roof strata displacement when advancing to $15 \mathrm{~m}$ (unit: $\mathrm{m}$ ): (a) slice of the $195 \mathrm{~m}$ working face in advancing direction, (b) slice of the $376 \mathrm{~m}$ working face in advancing direction, (c) lengthwise slice of the $195 \mathrm{~m}$ working face, and (d) lengthwise slice of the $376 \mathrm{~m}$ working face.

coal seam is $195 \mathrm{~m}$ and $376 \mathrm{~m}$, equation (6) is introduced, and the initial caving step length of each roof stratum is calculated according to plate theories, as shown in Table 2. The periodic caving step length of the old roof is often determined by the cantilever fracture of the old roof. According to the calculation of mechanics of materials, the initial caving step length is 2.45 times the periodic caving step length. The calculation results of the periodic caving step length are shown in Table 2.

3.3. Analysis of Fracture Characteristics of Roof Strata. According to the calculation results in Table 2, the fracture characteristics of roof strata are as follows:

(1) The roof caving mode of the goaf of the 3500 Working Face is successive layered caving. When the working face begins to advance from the cut, the first layer of carbonaceous mudstone caves in first, with a caving height of $0.3 \mathrm{~m}$. When the working face continues to advance to $18.4 \mathrm{~m}$, the second mudstone layer caves in, with the roof caving height of $1.7 \mathrm{~m}$. When it advances to $41.9 \mathrm{~m}$, the roof is covered with fine sandstone, and the mudstone on it is fractured. The fractured height of the roof is $7.3 \mathrm{~m}$. After that, the working face advances for three cycles; that is, when the working face advances to $45 \mathrm{~m}$, the fifth layer of fine sandstone is fractured, and the overlying mudstone, fine sandstone, and argillaceous sand- stone are fractured along with it, with the fractured height of the roof more than $31 \mathrm{~m}$

(2) The step length of the first caving of the immediate roof of the 3500 Working Face is $12 \mathrm{~m}$. The caving step length of the initial fracture of the main roof is about $35-37 \mathrm{~m}$. The periodic caving step length of the basic roof is $14-15 \mathrm{~m}$

(3) With the increase of the working face length, the roof rock stratum caving step length is basically unchanged. It can be considered that the working face length is in the range of $195 \mathrm{~m}$ to $376 \mathrm{~m}$, and the working face length has little influence on the roof caving step length. By comparing the caving step lengths of different rock strata, it can be inferred that the caving step lengths are positively correlated with the thickness of rock strata

\section{Study on Strata Behavior Law of Variable- Sized Working Faces through Numerical Simulation}

4.1. Construction of Numerical Calculation Models. In the numerical simulation, 3DEC is used to compare and analyze the deformation characteristics, movement law, and stress variation law of the roof in the process of advancing towards working face lengths of $195 \mathrm{~m}$ and $376 \mathrm{~m}[26,27]$. 


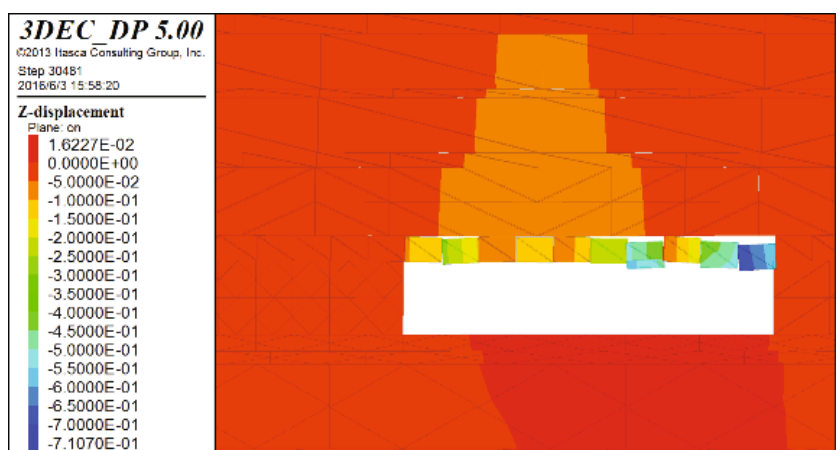

(a)

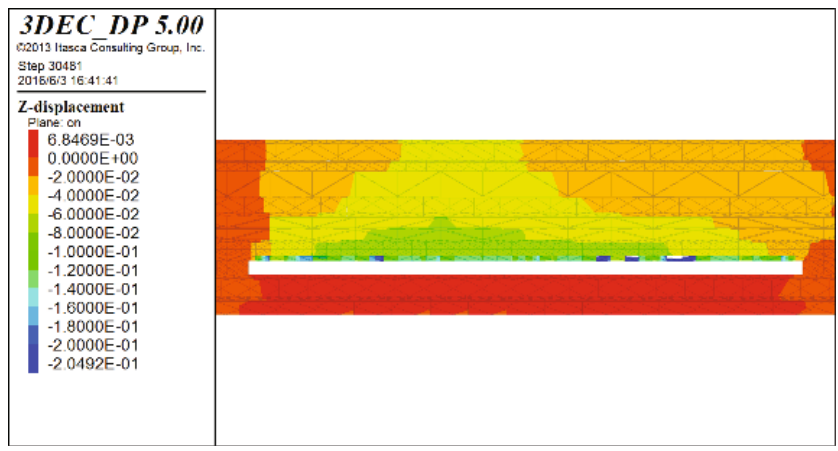

(c)

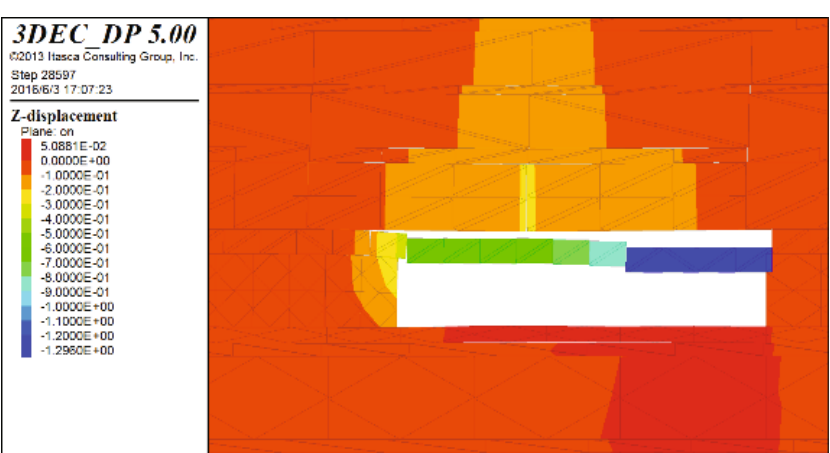

(b)

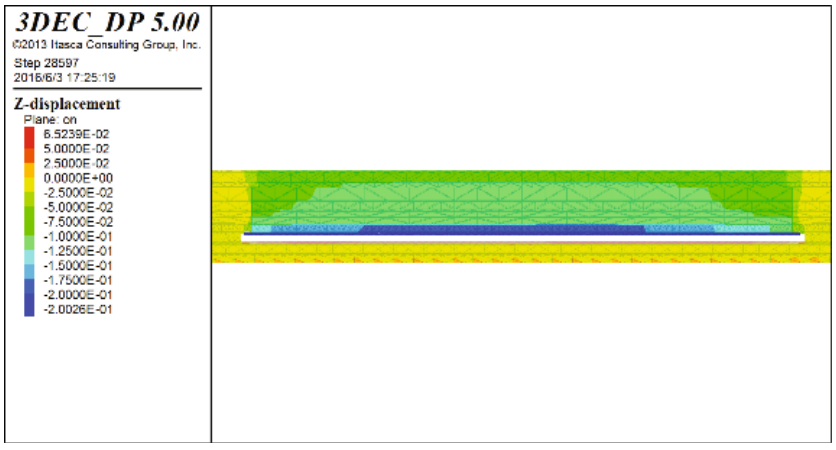

(d)

FIGURE 4: Nephogram of roof strata displacement when advancing to $30 \mathrm{~m}$ (unit: $\mathrm{m}$ ): (a) slice of the $195 \mathrm{~m}$ working face in advancing direction, (b) slice of the $376 \mathrm{~m}$ working face in advancing direction, (c) lengthwise slice of the $195 \mathrm{~m}$ working face, and (d) lengthwise slice of the $376 \mathrm{~m}$ working face.

(1) Establishment of the three-dimensional model. Assuming that the dip angle of each stratum in the model is 0 and the thickness is uniform, a three-dimensional calculation model within the study range is established according to the physical and mechanical parameter Table 1 of the roof and floor strata of coal seams. The model size of the $195 \mathrm{~m}$ working face is $400 \mathrm{~m} \times 495$ $\mathrm{m} \times 61.3 \mathrm{~m} \quad$ (length $\times$ width $\times$ height), with 13,610 deformable blocks which are divided into 334,440 units. The model size of the $376 \mathrm{~m}$ working face is $500 \mathrm{~m} \times$ $676 \mathrm{~m} \times 61.3 \mathrm{~m}$ (length $\times$ width $\times$ height), with 38,916 deformable blocks which are divided into 856,100 units. To analyze the study area more accurately and control the number of blocks within a reasonable range, the model is divided into unequal blocks. In the model, the Mohr-Coulomb constitutive model is adopted for the block, and the Coulomb friction model for the structural plane, with gravity $g=-9.81 \mathrm{~m} / \mathrm{s}^{2}$. The boundary conditions of the model are as follows: the bottom is fixed, the lateral side limits the horizontal displacement, and the upper part uses the stress boundary to simulate the compressive stress of overlying strata on the model

(2) Simulation of working faces and hydraulic support. After the calculation model reaches the initial state before mining, the excavate command of 3DEC software is used to simulate coal cutting. Every time the working face advances $2.5 \mathrm{~m}$ at a time, the fill com- mand is used to backfill the goaf formed by coal cutting and to assign a smaller elastic modulus, to simulate the supporting effect of the hydraulic support

(3) Interpretation of the model response. The threedimensional discrete element method is used for program analysis and calculation, to simulate stratification, fracturing, and caving of rock mass, and judge the state of rock mass and support by integrating the distribution of plastic zones, subsidence amount, and stress

4.2. Deformation Characteristics and Roof Migration Law. As the working face continues to advance, the deformation characteristics and migration laws of the roof under different advancing distances are compared and analyzed, as shown in Figure 3-9.

Figure 3 shows that the first caving step lengths of the immediate roof of the $195 \mathrm{~m}$ working face and the $376 \mathrm{~m}$ face are almost the same, at $15 \mathrm{~m}$. When the working face advances to $15 \mathrm{~m}$, the displacement of the roof of the $195 \mathrm{~m}$ working face is about $100 \sim 150 \mathrm{~mm}$, and the whole working face subsides evenly. The displacement of the roof of the $376 \mathrm{~m}$ working face is about $180 \sim 200 \mathrm{~mm}$, and the middle of the working face largely subsides.

Figure 4 shows that when the working face advances to $30 \mathrm{~m}$, the roof subsidence amount of the $195 \mathrm{~m}$ and the $376 \mathrm{~m}$ working faces increases, and the subsidence range of 


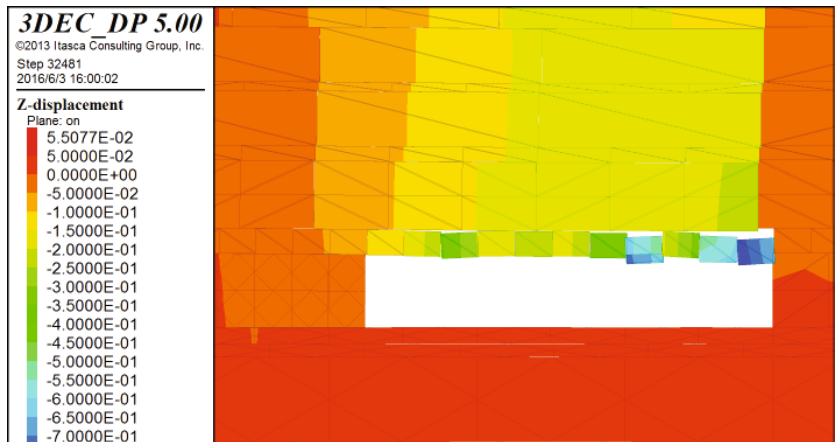

(a)

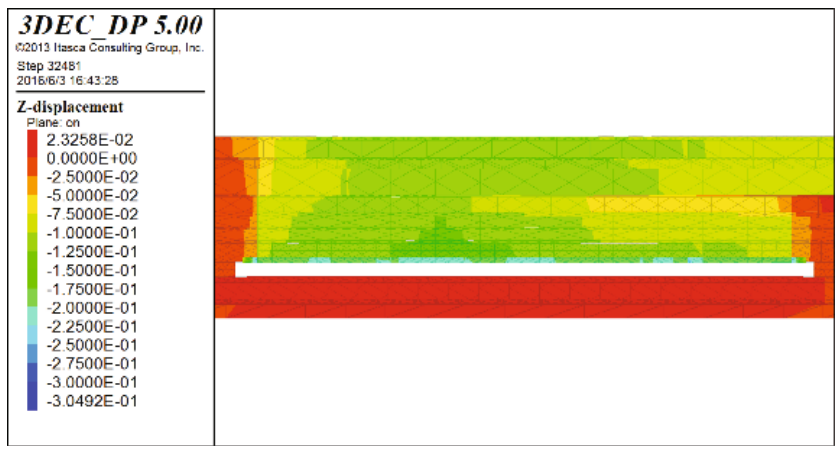

(c)

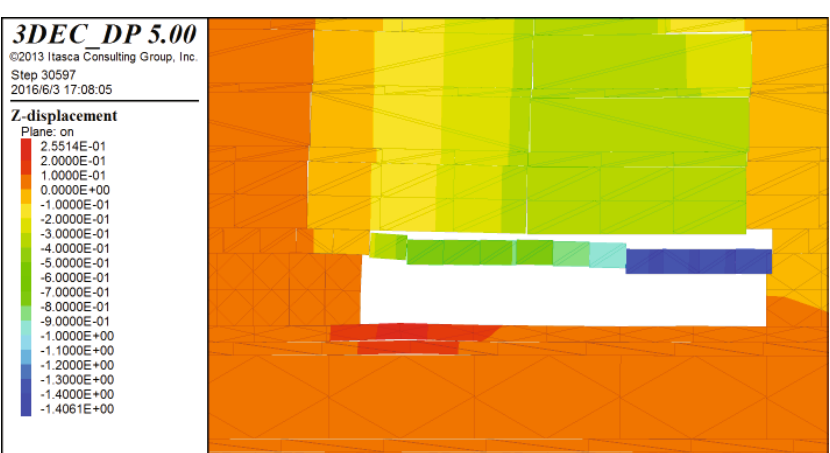

(b)

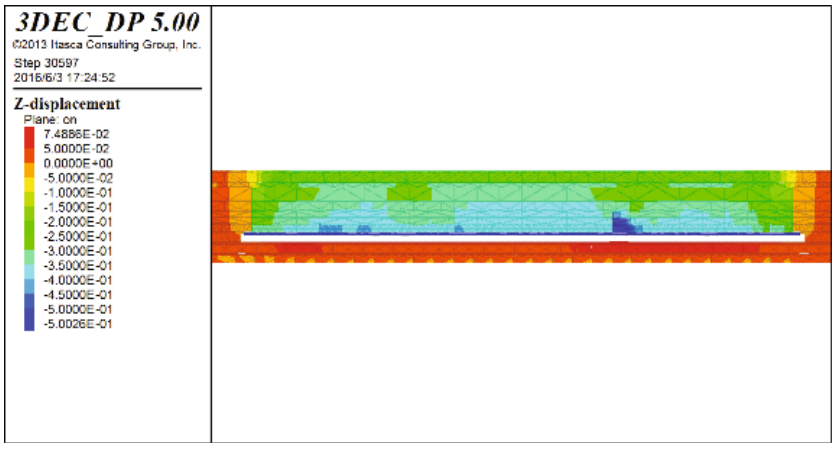

(d)

FIGURE 5: Nephogram of roof strata displacement when advancing to $32.5 \mathrm{~m}$ (unit: $\mathrm{m}$ ): (a) slice of the $195 \mathrm{~m}$ working face in advancing direction, (b) slice of the $376 \mathrm{~m}$ working face in advancing direction, (c) lengthwise slice of the $195 \mathrm{~m}$ working face, and (d) lengthwise slice of the $376 \mathrm{~m}$ working face.

the roof extends to the basic roof. At this time, the subsidence curve of the $195 \mathrm{~m}$ working face presents an asymmetric Gaussian distribution, in which the central axis deviates slightly to one end of the working face, with roof subsidence of $400 \sim 600 \mathrm{~mm}$. The roof subsidence of the $376 \mathrm{~m}$ working face is different. The roof of the $376 \mathrm{~m}$ working face shows integral subsidence. The initial fracture of the main roof occurs, and the masonry structure $[28,29]$ is formed, with roof subsidence of about $500 \sim 700 \mathrm{~mm}$.

Figure 5 shows that when the working face advances to $32.5 \mathrm{~m}$, the moving range of the roof of the $195 \mathrm{~m}$ working face continues to gradually expand, and the basic initial fracture of the main roof occurs, and the masonry structure is formed. The subsidence amount of the roof of the $376 \mathrm{~m}$ working face increases in local areas along the lengthwise direction of the working face.

Figure 6 shows that when the working face advances to $35 \mathrm{~m}$, both working faces show obvious subsidence. The difference is that the $195 \mathrm{~m}$ working face follows the subsidence rule of the Gaussian distribution curve, while the roof of the $376 \mathrm{~m}$ working face shows intermittent subsidence. Because the length of the $376 \mathrm{~m}$ working face is about twice that of the $195 \mathrm{~m}$ working face, the figure shows intermittent subsidence in two to three intervals. Therefore, it can be inferred that the roof subsidence of a super large working face can be regarded as the combined subsidence of several common working faces.

Figure 7 shows that when the working face advances to $37.5 \mathrm{~m}$, the damage range of the roof of both working faces continues to expand, and the subsidence amount of the roof continues to increase.

Figure 8 shows that the damage range of the roof of both working faces continues to extend to the upper part of the roof. The difference is that the deformation of each part in the lengthwise direction of the $195 \mathrm{~m}$ working face is quite different, and the $376 \mathrm{~m}$ working face is again characterized by uniform subsidence.

Figure 9 shows that when both working faces advance to $45 \mathrm{~m}$, the displacement and deformation of the roof of the $376 \mathrm{~m}$ working face is larger than that of the $195 \mathrm{~m}$ working face, and the roof is pressed periodically.

Through the above analysis, it can be concluded that the roof displacement of the $195 \mathrm{~m}$ working face follows the subsidence rule of the Gaussian distribution curve, while the roof of the $376 \mathrm{~m}$ working face shows intermittent subsidence. Moreover, it can be inferred that the roof subsidence of the super large working face is the combined subsidence of several common working faces.

\subsection{Comparison and Analysis of Roof Periodic Weighting} Law. Comparison and analysis of the periodic weighting intensity law of both working faces are shown in Figures 10 and 11.

Figure 10 shows that the periodic weighting of the $195 \mathrm{~m}$ working face is generally stable, which is high and even in the middle and low at both ends. Within $20 \mathrm{~m}$ of both ends, weighting gradually increases from $675 \mathrm{kPa}$ to $800 \mathrm{kPa}$. Within $20-175 \mathrm{~m}$ of the middle of the working face, 


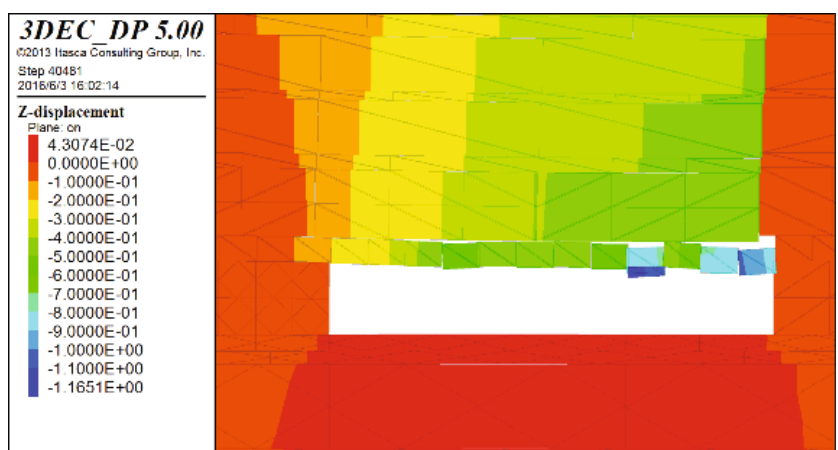

(a)

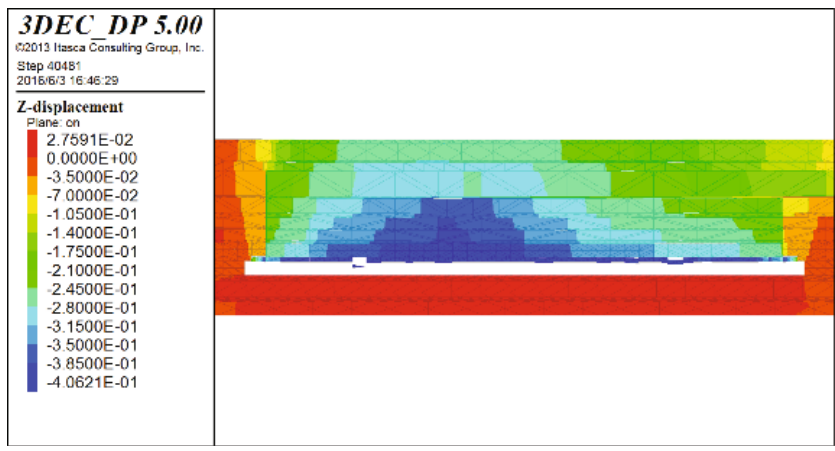

(c)

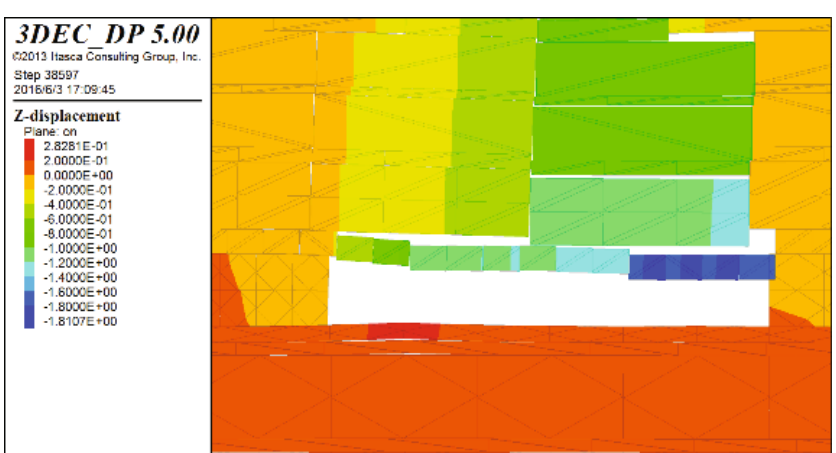

(b)

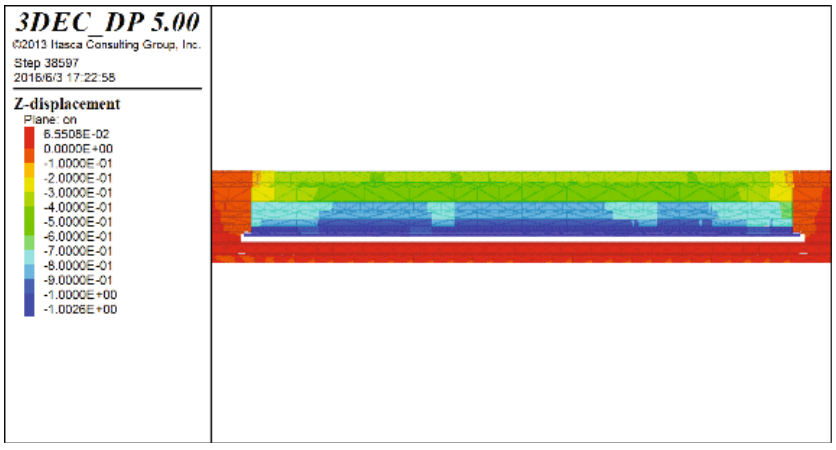

(d)

FIgURE 6: Nephogram of roof strata displacement when advancing to $35 \mathrm{~m}$ (unit: $\mathrm{m}$ ): (a) slice of the $195 \mathrm{~m}$ working face in advancing direction, (b) slice of the $376 \mathrm{~m}$ working face in advancing direction, (c) lengthwise slice of the $195 \mathrm{~m}$ working face, and (d) lengthwise slice of the $376 \mathrm{~m}$ working face.

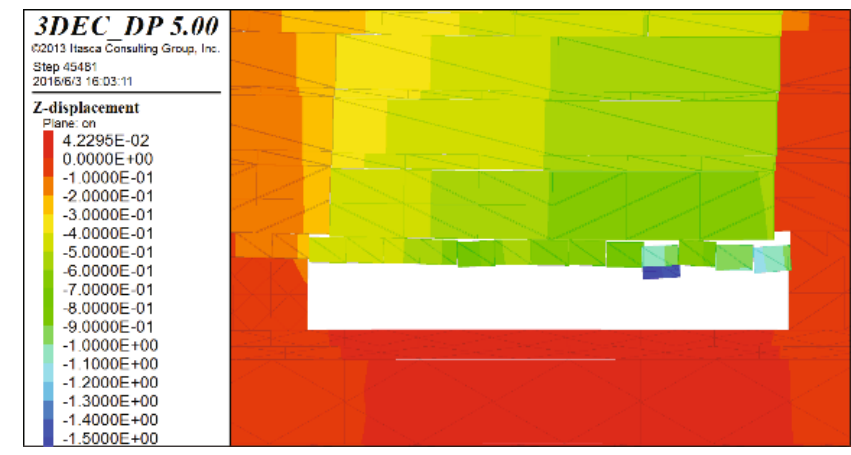

(a)

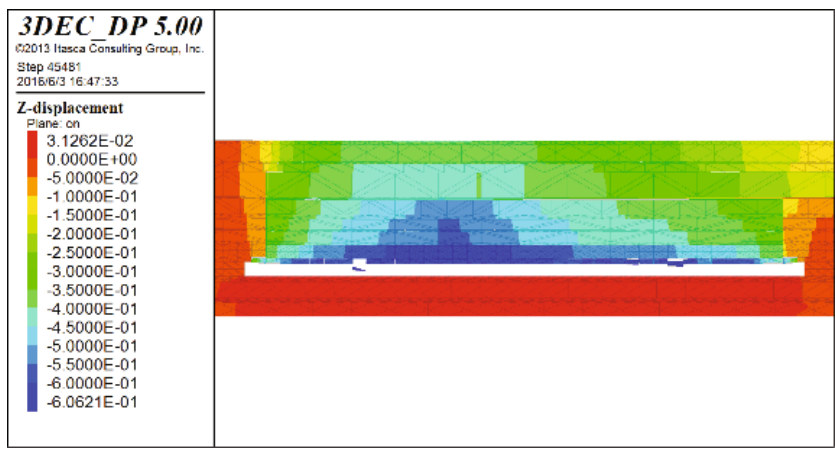

(c)

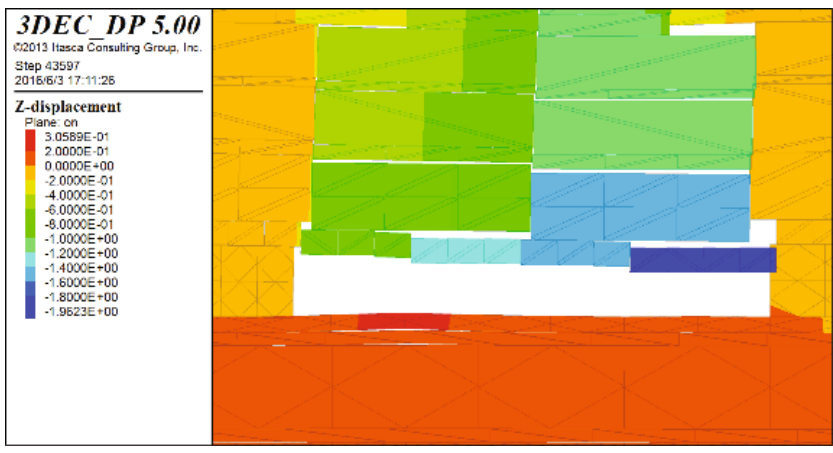

(b)

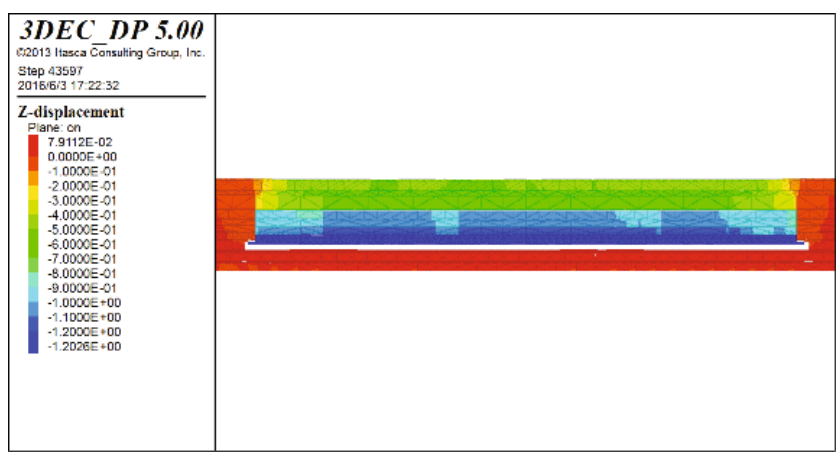

(d)

Figure 7: Nephogram of roof strata displacement when advancing to $37.5 \mathrm{~m}$ (unit: $\mathrm{m}$ ): (a) slice of the $195 \mathrm{~m}$ working face in advancing direction, (b) slice of the $376 \mathrm{~m}$ working face in advancing direction, (c) lengthwise slice of the $195 \mathrm{~m}$ working face, and (d) lengthwise slice of the $376 \mathrm{~m}$ working face. 


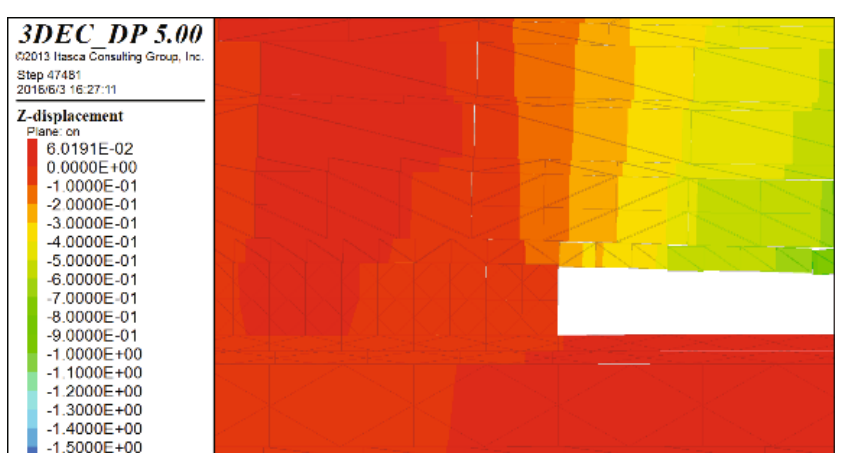

(a)

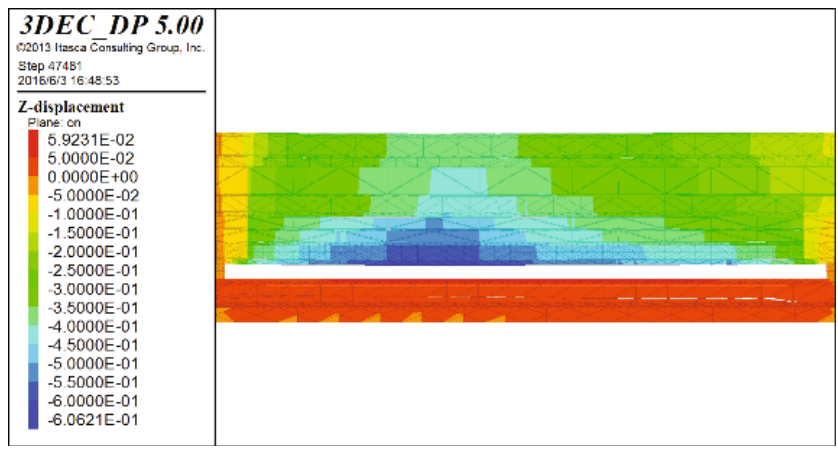

(c)

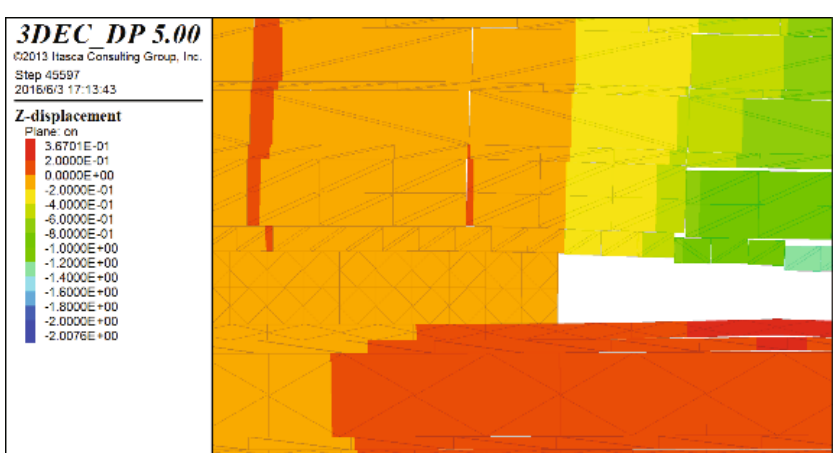

(b)

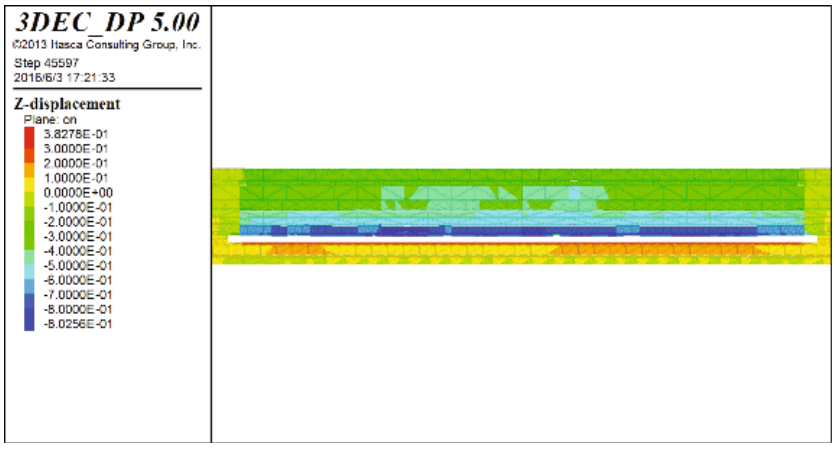

(d)

FIgURE 8: Nephogram of roof strata displacement when advancing to $40 \mathrm{~m}$ (unit: $\mathrm{m}$ ): (a) slice of the $195 \mathrm{~m}$ working face in advancing direction, (b) slice of the $376 \mathrm{~m}$ working face in advancing direction, (c) lengthwise slice of the $195 \mathrm{~m}$ working face, and (d) lengthwise slice of the $376 \mathrm{~m}$ working face.

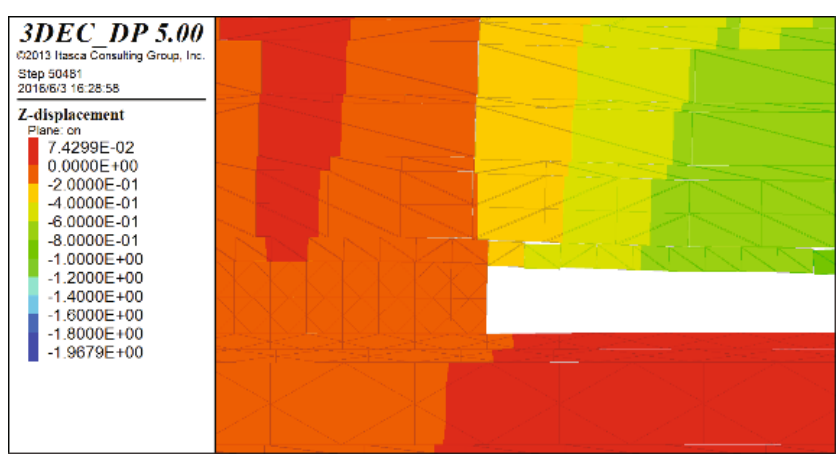

(a)

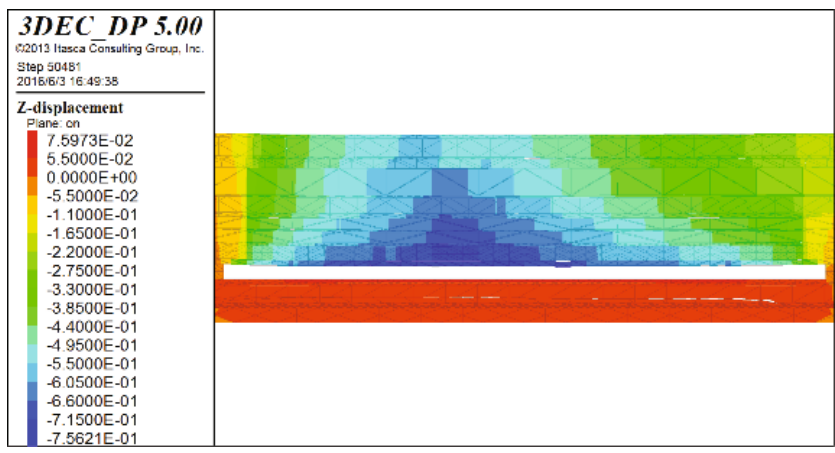

(c)

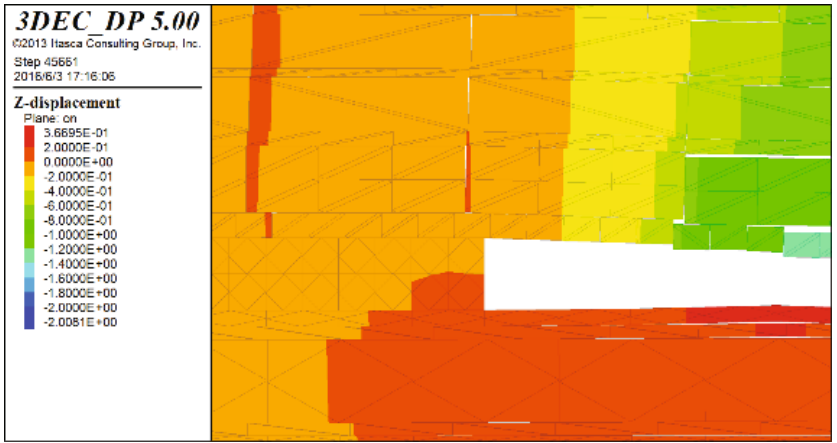

(b)

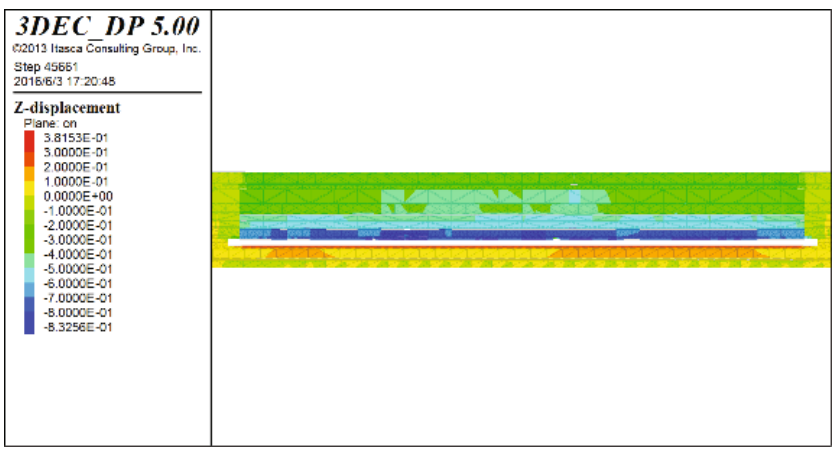

(d)

FIGURE 9: Nephogram of roof strata displacement when advancing to $45 \mathrm{~m}$ (unit: $\mathrm{m}$ ): (a) slice of the $195 \mathrm{~m}$ working face in advancing direction, (b) slice of the $376 \mathrm{~m}$ working face in advancing direction, (c) lengthwise slice of the $195 \mathrm{~m}$ working face, and (d) lengthwise slice of the $376 \mathrm{~m}$ working face. 


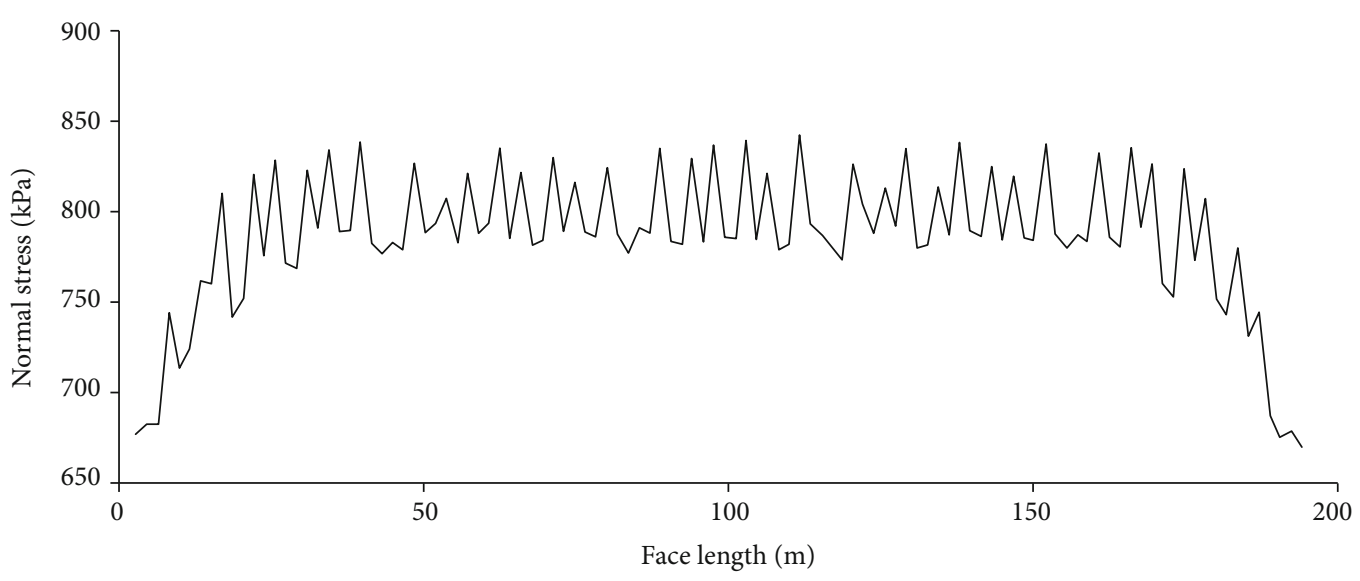

FIGURE 10: Weighting law of $195 \mathrm{~m}$ working face.

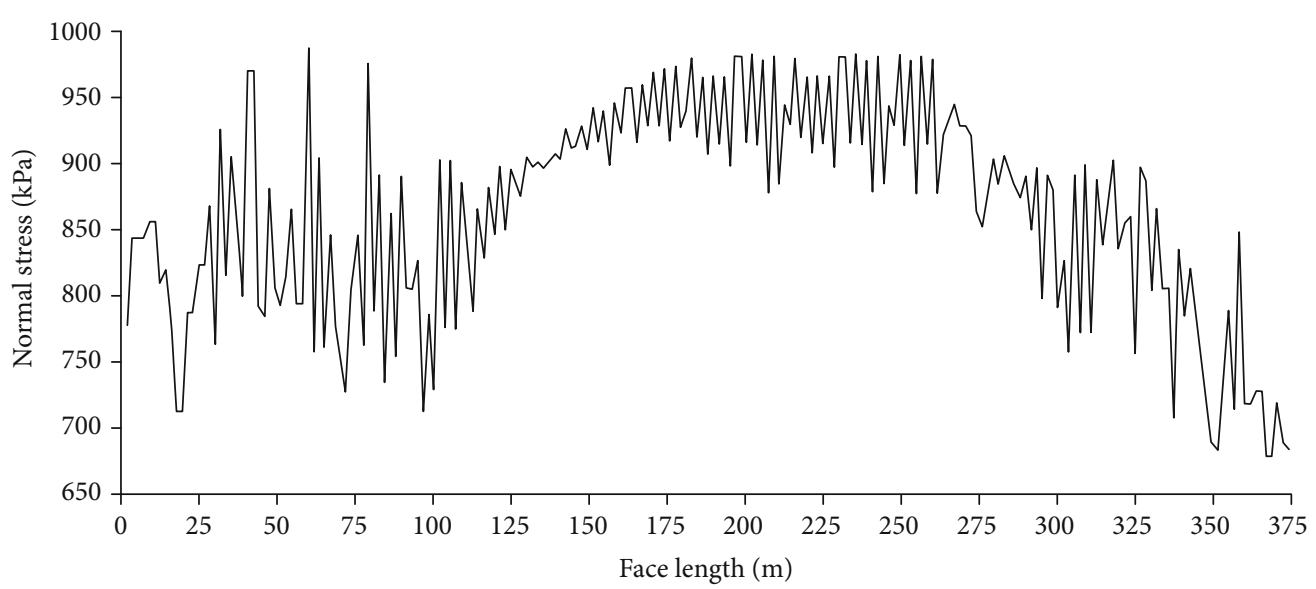

FIgURE 11: Weighting law of $376 \mathrm{~m}$ working face.

weighting is uniformly distributed, remaining basically stable at $800 \mathrm{kPa}$.

Figure 11 shows that the periodic weighting of the $376 \mathrm{~m}$ working face is generally high in the middle of the working face while low at both ends, fluctuating in a small range in the middle but oscillating violently at both ends. Within $100-275 \mathrm{~m}$ in the middle of the working face, there is arc fluctuation which is high in the middle and low at both ends, and the average weighting is maintained at $877.80 \mathrm{kPa}$. The maximum weighting is $985.67 \mathrm{kPa}$, and the minimum is $676.83 \mathrm{kPa}$ within $100 \mathrm{~m}$ from both ends. Weighting oscillation is obvious.

Comparing Figures 10 and 11 shows that the periodic weighting of the $376 \mathrm{~m}$ working face is more violent than that of the $195 \mathrm{~m}$ working face. The $376 \mathrm{~m}$ working face oscillates sharply within $100 \mathrm{~m}$ at both ends, while the $195 \mathrm{~m}$ working face gradually decreases from the middle of the working face to both ends. The average periodic weighting of the $376 \mathrm{~m}$ working face is about $80 \mathrm{kPa}$ higher than that of the $195 \mathrm{~m}$ working face. Through the above analysis, it can be concluded that the working resistance of the support needed in a super large working face is greater. Thus, attention should be paid to the intensity of support within $100 \mathrm{~m}$ of the end of the face.
TABLE 3: Statistical results of working resistance of hydraulic support in working faces.

\begin{tabular}{lcc}
\hline $\begin{array}{l}\text { Working face } \\
\text { length }(\mathrm{m})\end{array}$ & $\begin{array}{c}\text { Supporting } \\
\text { intensity }(\mathrm{kPa})\end{array}$ & $\begin{array}{c}\text { Working resistance } \\
\text { of support }(\mathrm{kN})\end{array}$ \\
\hline 195 & 880.2 & 8518.1 \\
242.4 & 921.4 & 9136.8 \\
376 & 991.2 & 9621.4 \\
\hline
\end{tabular}

\section{Measurements and Analysis of Working Resistance of Working Face Support}

The 3500 Working Face in the Wangzhuang Coal Mine is monitored and counted in real time, and the supporting strength of hydraulic support with different working face lengths is compared and analyzed. Through theoretical and numerical calculation and analysis, ZY10000/26/55D Twocolumn Shield Hydraulic Support is selected as the hydraulic support for the 3500 Working Face. Table 3 summarizes the statistics of working resistance for hydraulic support in working faces of three lengths: $195 \mathrm{~m}, 242.4 \mathrm{~m}$, and $376 \mathrm{~m}$.

The field measurement results show that the measured working resistance of support at $195 \mathrm{~m}$ and $242.2 \mathrm{~m}$ of 
working faces is within the rated working resistance range. In the $376 \mathrm{~m}$ working face, field measurement exceeded the rated working resistance in $2.76 \%$ of statistical cycles, among which the maximum working resistance is $10,049 \mathrm{kN}$ once and 10,098 kN twice. ZY10000/26/55D Hydraulic Support can meet the support requirements of super large working faces.

\section{Conclusions}

(1) Roof caving in goafs of the super large 3500 Working Face occurs as successive layered caving, with roof fracture height of more than $31 \mathrm{~m}$

(2) With the increase of the working face length, the caving step length of the roof stratum is basically unchanged. Working face length in the range of $195 \mathrm{~m}$ to $376 \mathrm{~m}$ has little effect on the roof weighting length. By comparing the caving step lengths of different rock strata, it can be inferred that the caving step length is positively correlated with the thickness of the rock stratum

(3) The roof displacement of the $195 \mathrm{~m}$ working face follows the subsidence rule of the Gaussian distribution curve, while the roof of the $376 \mathrm{~m}$ working face shows intermittent subsidence. Therefore, it can be inferred that the roof subsidence of the super large working face can be regarded as the combined subsidence of several common working faces

(4) The average periodic weighting of the $376 \mathrm{~m}$ working face, which is more violent, is about $80 \mathrm{kPa}$ higher than that of the $195 \mathrm{~m}$ working face. The $376 \mathrm{~m}$ working face is characterized by violent oscillation at both ends and fluctuations within a small range in the middle. Weighting increases gradually within $20 \mathrm{~m}$ of the end of the $195 \mathrm{~m}$ working face, and the middle of the working face shows uniform weighting

(5) Comparison and analysis of the statistical results of the field working resistance of working faces of $195 \mathrm{~m}, 242.4 \mathrm{~m}$, and $376 \mathrm{~m}$ length confirm that ZY10000/26/55D Hydraulic Support can meet the requirements of super large working faces

\section{Data Availability}

The data used to support the findings of the study are available from the corresponding author upon request.

\section{Additional Points}

Open Access. This article is distributed under the terms of theCreative Commons Attribution 4.0 International License (http://creativecommons.org/licenses/by/4.0/), which permits unrestricted use, distribution, and reproduction in any medium, provided you give appropriate credit to the original authors and the source, provide a link to the Creative Commons license, and indicate if changes were made.

\section{Conflicts of Interest}

All authors declare that they have no conflict of interest or financial conflicts to disclose.

\section{Acknowledgments}

The authors gratefully acknowledge the financial support provided by the National Natural Science Foundation of China (Grant Number 51904199), the Shanxi Provincial Key Research and Development Program (High-tech Field) Project (201903D121075), Transformation of Scientific and Technological Achievements Programs of Higher Education Institutions in Shanxi (Grant Number JYT2019015), and the Natural Science Foundation for Young Scientists of Shanxi Province (201801D221328).

\section{References}

[1] A. Mohammadreza, S. Vahab, and D. Hesam, "Evaluation of plow system performance in long-wall mining method using particle flow code," International Journal of Coal Science Technology, vol. 6, no. 4, pp. 518-535, 2019.

[2] S. P. Peng, "Current status and prospects of research on geological assurance system for coal mine safe and high efficient mining," Journal of China Coal Society, vol. 45, no. 7, pp. 2331-2345, 2020.

[3] M. G. Qian, J. L. Xu, and J. C. Wang, "Further on the sustainable mining of coal," Journal of China Coal Society, vol. 43, no. 1, pp. 1-13, 2018.

[4] J. W. Teng, Y. H. Qiao, and P. H. Song, "Analysis of exploration, potential reserves and high efficient utilization of coal in China," Chinese Journal of Geophysics, vol. 59, no. 12, pp. 4633-4653, 2016.

[5] Y. M. Zhang and X. Zhang, "Research on strata-pressure behavior of large mining height at fully mechanized mining face in shallow seam," Coal Technology, vol. 35, no. 11, pp. 65-67, 2016.

[6] H. P. Kang, G. Xu, B. M. Wang et al., "Forty years development and prospects of underground coal mining and strata control technologies in China," Journal of Mining and Strata Control Engineering, vol. 1, no. 2, pp. 7-39, 2019.

[7] G. F. Wang, J. H. Zhang, Y. J. Xu et al., "Supporting stress characteristics and zonal cooperative control technology of long working face in deep thick coal seam," Journal of China Coal Society, vol. 46, no. 3, pp. 763-773, 2021.

[8] X. M. Song, T. F. Gu, and Z. H. Yan, "Effects of increasing working face's length on underground pressure behaviors of mining super-high faces under shallow coal seam," Chinese Journal of Rock Mechanics and Engineering, vol. S2, pp. 4007-4012, 2007.

[9] H. P. Kang, G. F. Wang, P. F. Jiang et al., "Conception for strata control and intelligent mining technology in deep coal mines with depth more than 1000m," Journal of China Coal Society, vol. 43, no. 7, pp. 1789-1800, 2018.

[10] X. W. Zhang, "Technical research and practice of fully mechanized long working face," Coal science and technology, vol. 8, 2007.

[11] Z. Huang, "Thoughts on developing super large mines in China," Coal Engineering, vol. 41, no. 9, pp. 5-7, 2009. 
[12] W. B. Guo and Y. G. Wang, "The definition of high-intensity mining basedon green coal mining and its index system," Journal of Mining and Safety Engineering, vol. 34, no. 4, pp. 616623, 2017.

[13] L. B. Song and Q. X. Wang, "Study on safety mining technology of China first $450 \mathrm{~m}$ ultra long fully mechanized coal mining face," Coal engineering, vol. 46, no. 3, 2014.

[14] Q. X. Wang and J. F. Ju, "Study on mine strata pressure behavior law of $450 \mathrm{~m}$ ultra long fully-mechanized coal mining face," Coal Science and Technology, vol. 42, no. 3, pp. 125-128, 2014.

[15] M. S. Yi, "Selection of mechanized working face length by great height mining under shallow coal-seam in Shendo coal district," Journal of China Coal Society, vol. 12, pp. 1253-1257, 2007.

[16] X. D. Li, "Study on the coal pressure appearance rule of large cutting height and super length workface in Sihe coal mine," Energy and Energy Conservation, vol. 16, no. 4, pp. 85-87, 2011.

[17] G. F. Wang, F. Liu, X. J. Meng et al., "Research and practice on intelligent coal mine construction (primary stage)," Coal Science and Technology, vol. 47, no. 8, 2019.

[18] D. Z. Kong, W. Jiang, Y. Chen, Z. Y. Song, and Z. Q. Ma, "Study of roof stability of the end of working face in upward longwall top coal," Arabian Journal of Geosciences, vol. 10, no. 8, p. 185, 2017.

[19] W. R. Liu, "Experimental and numerical study of rock stratum movement characteristics in longwall mining," Shock and Vibration, vol. 2019, 2019.

[20] M. Z. Gao, J. Xie, Y. N. Gao et al., "Mechanical behavior of coal under different mining rates: a case study from laboratory experiments to field testing," International Journal of Mining Science and Technology, 2021.

[21] B. N. Wang, F. N. Dang, W. Chao, Y. P. Miao, J. Li, and F. Chen, "Surrounding rock deformation and stress evolution in pre-driven longwall recovery rooms at the end of mining stage," International Journal of Coal Science Technology, vol. 6, no. 4, pp. 536-546, 2019.

[22] X. Wang, Z. J. Wen, Y. J. Jiang, and H. Huang, "Experimental study on mechanical and acoustic emission characteristics of rock-like material under non-uniformly distributed loads," Rock Mechanicsand Rock Engineering, vol. 51, no. 3, pp. 729745, 2018.

[23] J. C. Wang, S. L. Yang, B. G. Yang et al., "Roof sub-regional fracturing and support resistance distribution in deep longwall face with ultralarge length," Journal of China Coal Society, vol. 44, no. 1, pp. 54-63, 2019.

[24] J. L. Zhou and Q. H. Huang, "Stability analysis of key roof layer structure in shallow buried large mining height face," Chinese Journal of Rock Mechanics and Engineering, vol. 38, no. 7, pp. 1396-1407, 2019.

[25] K. Yang, Z. Wei, X. L. Chi, A. S. Gao, and Q. Fu, "Fracture criterion of basic roof deformation in fully mechanized mining with large dip angle," Energy Exploration and Exploitation, vol. 39, no. 3, pp. 886-902, 2021.

[26] W. Wang, Y. P. Cheng, H. F. Wang, W. Li, and L. Wang, "Coupled disaster-causing mechanisms of strata pressure behavior and abnormal gas emissions in underground coal extraction," Environmental Earth Sciences, vol. 74, no. 9, pp. 6717-6735, 2015.

[27] W. F. Yang and X. H. Xia, "Study on mining failure law of the weak and weathered composite roof in a thin bedrock working face," Journal of Geophysics and Engineering, vol. 15, no. 6, pp. 2370-2377, 2018.

[28] Y. W. Lan, R. Gao, B. Yu, and X. B. Meng, "In situ studies on the characteristics of strata structures and behaviors in mining of a thick coal seam with hard roofs," Energies, vol. 11, no. 9, p. 2470, 2018.

[29] Y. H. Zhao and X. M. Song, "Stability analysis and numerical simulation of hinged arch structure for fractured beam in super-long mining workface under shallow seam," Rock and Soil Mechanics, vol. 37, no. 1, pp. 203-209, 2016. 